UDC: $633.71: 575.2$

COBISS.SR-ID: 211610124

Original research paper

Acta Agriculturae Serbica, Vol. XIX, 37 (2014); 61-69

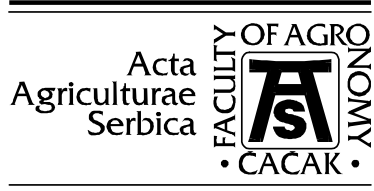

\title{
Inheritance of the height of plants and number of leaves by hybrid combination Virginia tobacco
}

\author{
Yovko Dyulgerski \\ Tobacco and Tobacco Products Institute (TTPI), Markovo, Bulgaria \\ (e-mail:yovko_dulg@abv.bg)
}

\begin{abstract}
Studied are inheritance, acts of heterosis and transgression, the number of genes and genetic character of Interaction, heritability coefficients, in terms of plant height and number of leaves in crosses Virginia tobacco. For the purpose of the study population are $\mathrm{P}_{1}, \mathrm{P}_{2}, \mathrm{~F}_{1}$ and $\mathrm{F}_{2}$ of seven hybrid combinations. In our study samples Virginia tobacco inheritance of plant height and number of leaves overdominantly or additively, in the direction of the parent with the higher or lower values. Data of the genetic analysis showed that the number of genes affecting the expression of the trait plant height is 13 to 16 , and when the number of leaves - 1 or 2 . As regards the height of the plants is observed negative epistaz, while the number of leaves and less positive one. Are established a high coefficient of heritability of plant height and number of leaves of a plant. The coefficients for the heritability and efficiency in selection by phenotype indicate that the selection of genotypes with larger values of the height of the plants will be more effective in the $\mathrm{F}_{5}-\mathrm{F}_{6}$, and the genotype of a large number of leaves in the still earlier hybrid generations.
\end{abstract}

Key words: Virginia tobacco, height of plants, number of leaves, inheritance, hereditability.

Received: 18. 02. 2014. / Accepted: 15. 11. 2014. 


\section{Introduction}

The height of plants and the number of leaves is one of the most important varieties characteristics of the tobacco (Kirkova, 2005; Radoukova, 2008; Risteski et all, 2012).

The feature height of plants is polygenic determined and strongly influenced by environmental conditions (Ganusheva et all. 2001; Murzova et all, 2005). Krasteva (1983) observed overdominantly inheritance of plant height in Virginia and Burley tobaccos. Sastry and Rrasada Rao (1980) in Burley tobacco found that with prevailing important for the sign are the dominant gene effects. According to Metha et all. (1985) in crosses of Bidi tobacco and according Torrecila and Barroso (1980) in large-leaf tobacco, inheritance of plant height are observed as additive and notadditive (dominant and epistative) gene effects. Chang et all (1980) at Virginia tobacco for height of the plants found that the main type of inheritance is additive. When inheriting of the trait plant height, more important are the dominant effects of the additive (Chinchev, 1979). Noveva et all (1984) found dominantly and overdominantly inheritance in $F_{1}$ hybrid combinations of tobacco Virginia, while hybrids with participation of Burley tobacco dominantly.

The number of leaves is mostly inherited dominantly and semidominantly against parent with a greater number of leaves (Caneva, 1980; Vassilev 2010). Sastry and Rrasada Rao (1980) reported that the mode of inheritance of the number of leaves in Virginia with the most important is dominant and additive gene effects. Chang et all. (1980); Sastry and Rrasada Rao (1980) in crosses of Burley tobacco found that the number of leaves prevailing dominant gene effects. Torrecila and Barroso (1980) found that the largest share of additive gene effects. According Noveva et all. (1984) most influenced by epistative gene like the action of the dominant significantly superior that of additive gene effects. Methaet all. (1985) reported that the number of leaves is controlled both by the additive and by noradditive effects.

Ibrahim and Avratovscukova, (1982), Amarnath, (1987), Dimanov (2003), Peksuslu et al., (2002) Stankev (2001) and Naumovski (1988) obtained in $\mathrm{F}_{2}$ heritability coefficients with higher values for the height plants and the number of leaves, which allows for the rapid and stabilization in the subsequent generations.

The purpose of this study is by application of genetic analysis to identify the character of inheritance, the manifestations of heterosis and transgression, the number of genes that differ in the starting parent form, the extent of genetic interaction, coefficient of heritability and mass selection with respect to the feature height plants and the number of leaves for selection of desirable genotypes Virginia tobacco. 


\section{Materials and methods}

For the realization of its objective were tested populations $\mathrm{P}_{1}, \mathrm{P}_{2}, \mathrm{~F}_{1}$ and $\mathrm{F}_{2}$ of seven Virginia tobacco crosses, namely: Hybrid 719 (RG 8 x L 358); Hybrid 720 (L 250 x C 254); Hybrid 721 ( L 250 x L 358); Hybrid 722 (K 730 x C 254); Hybrid 723 (K 730 x L 358); Hybrid 725 (K 326 x C 254); Hybrid 727 (K 326 $\mathrm{x}$ L 358). Are studied the plant height and number of leaves. Biometric measurements were made on 300 plants of option. The experimental work was carried out in the experimental field-study of TTPI - Markovo in the period 2010 $-2011$.

Regarding the height of the plants and the number of leaves were determined: the arithmetic mean $(\bar{x})$, the average error of the arithmetic mean ( $\mathrm{S} \bar{x} \%$ ), degree of dominance (domination extent) (d/a) in the formula of Mather and Jinks (1985), heterosis effect to better parental form (HP) in Omarov (1975). Have been identified: an indicator of transgression (Tn), the number of genes that differ in parental forms (N), dominance (D), epiztaz (E) coefficient of heritability $\left(\mathrm{H}^{2}\right)$, coefficient of effective selection by genotypes in phenotypic expression of the trait (Pp) by Sobolev (1976).

\section{Results and Discussion}

In tested hybrid combinations of Virginia tobacco, inheritance of plant height is overdominantly except Hybrid 719 (RG 8 x L 358), where is incompletely dominant. Inheritance is as a parent in a direction of greater values of the manifestation of signs, and the one with the smaller value (Table 1).

Heterosis effect on plant height in crosses studied is negligible (Table 1). Heterosis of significant figures only occurs in Hybrid 722 (K $730 \times$ C 254) and its manifestation is the limit of significance.

The values of the coefficient of transgression indicate minor values on plant height (Table 2). The results show that heterosis and transgression such expression have less importance in the selection of Virginia tobacco with respect to the studies indicator. 
Table 1. Biometric data of height of the plants $/ \mathrm{cm} /$ )

\begin{tabular}{lcccccc}
\hline $\begin{array}{l}\text { Кръстоски } \\
\text { Crosses }\end{array}$ & $\bar{x} \pm \mathrm{S} \bar{x}$ & $\bar{x} \pm \mathrm{S} \bar{x}$ & $\bar{x} \pm \mathrm{S} \bar{x}$ & $\bar{x} \pm \mathrm{S} \bar{x}$ & $\mathrm{~d} / \mathrm{a}$ & $\mathrm{HP}$ \\
\hline $\begin{array}{l}\text { Hybrid 719 } \\
\text { RG 8 x L 358) }\end{array}$ & $159,4 \pm 0,71$ & $173,2 \pm 0,70$ & $173,9 \pm 0,74$ & $169,3 \pm 0,82$ & 0,7 & 0,4 \\
$\begin{array}{l}\text { Hybrid 720 } \\
\text { (L 250 x C 254) }\end{array}$ & $164,6 \pm 0,65$ & $162,7 \pm 0,58$ & $171,2 \pm 0,71$ & $165,6 \pm 0,79$ & 7,9 & 4 \\
$\begin{array}{l}\text { Hybrid 721 } \\
\text { (L 250 x L 358) }\end{array}$ & $164,6 \pm 0,65$ & $173,2 \pm 0,70$ & $172,3 \pm 0,75$ & $168,8 \pm 0,87$ & $-5,2$ & - \\
$\begin{array}{l}\text { Hybrid 722 } \\
\text { (K 730 x C 254) }\end{array}$ & $166,5 \pm 0,61$ & $162,7 \pm 0,58$ & $175,5 \pm 0,66$ & $171,4 \pm 0,78$ & 5,7 & 5,4 \\
$\begin{array}{l}\text { Hybrid 723 } \\
\text { (K 730 x L 358) }\end{array}$ & $166,5 \pm 0,61$ & $173,2 \pm 0,70$ & $173,5 \pm 0,74$ & $168,2 \pm 0,85$ & $-3,1$ & 0,2 \\
$\begin{array}{l}\text { Hybrid 725 } \\
\text { (K 326 x C 254) }\end{array}$ & $161,8 \pm 0,52$ & $162,7 \pm 0,58$ & $168,9 \pm 0,78$ & $164,4 \pm 0,89$ & 5,8 & 3,8 \\
$\begin{array}{l}\text { Hybrid 727 } \\
\text { (K 326 x L 358) }\end{array}$ & $161,8 \pm 0,52$ & $173,2 \pm 0,70$ & $174,1 \pm 0,73$ & $170,8 \pm 0,84$ & $-4,8$ & 0,5 \\
\hline
\end{tabular}

Table 2.Genetic characteristic of height of the plants

\begin{tabular}{lcccccc}
\hline $\begin{array}{l}\text { Кръстоски } \\
\text { Crosses }\end{array}$ & Тп & $\mathrm{N}$ & $\mathrm{D}$ & $\mathrm{E}$ & $\mathrm{H}^{2}$ & $\mathrm{Pp}$ \\
\hline $\begin{array}{l}\text { Hybrid 719 } \\
\text { (RG 8 x L 358) }\end{array}$ & 0,12 & 12,72 & $\mathbf{9 , 6 9}$ & $-54,21$ & 0,672 & 0,561 \\
$\begin{array}{l}\text { Hybrid 720 } \\
\text { (L 250 x C 254) }\end{array}$ & $\mathbf{0 , 3 1}$ & $\mathbf{1 4 , 4 3}$ & $\mathbf{1 2 , 1 7}$ & $\mathbf{- 5 9 , 1 4}$ & $\mathbf{0 , 7 6 6}$ & $\mathbf{0 , 6 2 6}$ \\
$\begin{array}{l}\text { Hybrid 721 } \\
\text { (L 250 x L 358) }\end{array}$ & $\mathbf{- 0 , 1 5}$ & $\mathbf{1 3 , 9 3}$ & $\mathbf{9 , 8 4}$ & $\mathbf{- 6 2 , 3 4}$ & $\mathbf{0 , 7 0 7}$ & $\mathbf{0 , 6 1 0}$ \\
$\begin{array}{l}\text { Hybrid 722 } \\
\text { (K 730 x C 254) }\end{array}$ & $\mathbf{0 , 4 6}$ & $\mathbf{1 4 , 2 1}$ & $\mathbf{1 0 , 6 0}$ & $\mathbf{- 7 0 , 4 5}$ & $\mathbf{0 , 7 5 4}$ & $\mathbf{0 , 6 4 7}$ \\
$\begin{array}{l}\text { Hybrid 723 } \\
\text { (K 730 x L 358) }\end{array}$ & $\mathbf{- 0 , 0 3}$ & $\mathbf{1 5 , 7 7}$ & $\mathbf{1 1 , 5 1}$ & $\mathbf{- 5 2 , 1 1}$ & $\mathbf{0 , 6 5 2}$ & $\mathbf{0 , 5 8 2}$ \\
$\begin{array}{l}\text { Hybrid 725 } \\
\text { (K 326 x C 254) }\end{array}$ & $\mathbf{0 , 2 2}$ & $\mathbf{1 5 , 3 5}$ & $\mathbf{1 0 , 3 6}$ & $\mathbf{- 4 9 , 2 7}$ & $\mathbf{0 , 8 3 2}$ & $\mathbf{0 , 7 2 0}$ \\
$\begin{array}{l}\text { Hybrid 727 } \\
\text { (K 326 x L 358) }\end{array}$ & $\mathbf{0 , 1 6}$ & $\mathbf{1 6 , 0 8}$ & $\mathbf{1 1 , 2 3}$ & $\mathbf{- 6 4 , 0 9}$ & $\mathbf{0 , 7 2 5}$ & $\mathbf{0 , 6 3 3}$ \\
\hline
\end{tabular}

Data of the genetic analysis showed that the number of genes affecting the expression of the studies sign in which different parental forms varied slightly from 13 to 16 (Table 2). Strongly influenced by negative epistative interactions reduce that the expression of dominatn genes whose number also fluctuated in a narrow range. 
Established high values of the coefficient of heritability, especially in Hybrid 725 (K $326 \times 254$ C) show that on the phenotypic expression of the trait external factors did not significantly influence (Table № 2). There is therefore a very high proportion of the effect of genotype on the expression of the trait plant height. $t$ follows that the selection that signs will be effective in the early hybrid generations. The manifested negative epistaz however inhibits the expression of the trait plant height and despite the high participation of genotype, as evidenced by heritability coefficients; it probably will not allow the manifestation of high stalk in early generations.

The number of leaves in tobacco studies samples inherited diverse. It is overdominantly in Hybrid 720, Hybrid 725 and Hybrid 722, particularly pronounced in the last. Additive inheritance is observed in Hybrid 721, Hybrid 723 and Hybrid 727. In Hybrid 719 it is more like dominant. Inheritance, similar to the height of the plant is, as relative to the parent forms of a larger number and a smaller number of leaves (Table 3 ).

Compared to the plant height, according to number of leaves the heterosis effect is more pronounced. Heterosis of significant figures is found in crosses Hybrid 720 (L 250 x C 254), Hybrid 722 (K 730 x C 254) and Hybrid 725 (K $326 \times$ C 254), while the last two, it exceeds $10 \%$ (Table 3). This indicates that heterosis is a perspective, on increasing the number of leaves of the plants in Virginia tobacco.

Table3. Biometric data of number of leaves

\begin{tabular}{|c|c|c|c|c|c|c|}
\hline $\begin{array}{l}\text { Кръстоски } \\
\text { Crosses }\end{array}$ & $\bar{x}_{ \pm \mathrm{S}}^{\mathrm{P}_{1}} \bar{x}$ & $\begin{array}{c}\mathrm{P}_{2} \\
\bar{x} \pm \mathrm{S} \bar{x}\end{array}$ & $\begin{array}{c}\mathrm{F}_{1} \\
\mathrm{x} \pm \mathrm{Sx} \%\end{array}$ & $\begin{array}{c}\mathrm{F}_{2} \\
\mathrm{x} \pm \mathrm{Sx} \%\end{array}$ & $\mathrm{~d} / \mathrm{a}$ & HP \\
\hline $\begin{array}{l}\text { Hybrid } 719 \\
\text { (RG } 8 \text { x L 358) }\end{array}$ & $26,8 \pm 0,13$ & $29,3 \pm 0,16$ & $29,5 \pm 0,17$ & $28,4 \pm 0,19$ & $-1,1$ & 0,7 \\
\hline $\begin{array}{l}\text { Hybrid } 720 \\
\text { (L } 250 \times \text { C 254) }\end{array}$ & $28,3 \pm 0,11$ & $26,2 \pm 0,08$ & $30,5 \pm 0,12$ & $29,0 \pm 0,21$ & 3,1 & 7,8 \\
\hline $\begin{array}{l}\text { Hybrid } 721 \\
\text { ( L } 250 \text { x L 358) }\end{array}$ & $28,3 \pm 0,11$ & $29,3 \pm 0,16$ & $28,9 \pm 0,15$ & $27,3 \pm 0,19$ & $-0,4$ & $-1,4$ \\
\hline $\begin{array}{l}\text { Hybrid } 722 \\
(\text { K } 730 \text { x C 254) }\end{array}$ & $26,6 \pm 0,12$ & $26,2 \pm 0,08$ & $29,7 \pm 0,12$ & $28,5 \pm 0,16$ & 16,5 & 11,7 \\
\hline $\begin{array}{l}\text { Hybrid } 723 \\
\text { (K } 730 \text { x L 358) }\end{array}$ & $26,6 \pm 0,12$ & $29,3 \pm 0,16$ & $29,9 \pm 0,16$ & $27,8 \pm 0,20$ & $-0,8$ & 2,1 \\
\hline $\begin{array}{l}\text { Hybrid } 725 \\
\text { (K } 326 \times \text { C } 254)\end{array}$ & $25,9 \pm 0,07$ & $26,2 \pm 0,08$ & $29,4 \pm 0,11$ & $27,6 \pm 0,14$ & 3,2 & 12,2 \\
\hline $\begin{array}{l}\text { Hybrid } 727 \\
\text { (K 326 x L 358) }\end{array}$ & $25,9 \pm 0,07$ & $29,3 \pm 0,16$ & $29,6 \pm 0,18$ & $28,1 \pm 0,22$ & 0,3 & 1 \\
\hline
\end{tabular}

Acts of transgression with significant values were observed in three of the studied hybrid combinations (Table 4). In available homozygous offspring in Hybrid 720 (L $250 \times$ C 254), Hybrid 722 (K 730 x C 254) and Hybrid 725 (K 326 x C 254), can be selected plants with more than 1 leaf silkworm forms. 
Transgression occurs in these hybrid combinations in which exhibited heterosis, showing that the presence of heterosis presupposes the existence and of transgression.

Data of the genetic analysis (Table 4) show that the number of genes, the expression determining the sign of studies is very small and almost no varies - 1 or 2. This facilitates the selection work on this feature. Positive epistative interactions that even if not highly developed influence the phenotypic expression of the trait number of leaves of a plant.

Table 4. Genetic characteristic of number of leaves

\begin{tabular}{lcccccc}
\hline $\begin{array}{l}\text { Кръстоски } \\
\text { Crosses }\end{array}$ & $\mathrm{T}_{\text {п }}$ & $\mathrm{N}$ & $\mathrm{D}$ & $\mathrm{E}$ & $\mathrm{H}^{2}$ & Pр \\
\hline $\begin{array}{l}\text { Hybrid 719 } \\
\text { (RG 8 x L 358) }\end{array}$ & $\mathbf{0 , 0 9}$ & $\mathbf{2 , 2 6}$ & $\mathbf{1 , 6 3}$ & $\mathbf{5 , 2 3}$ & 0,582 & $\mathbf{0 , 3 5 5}$ \\
$\begin{array}{l}\text { Hybrid 720 } \\
\text { (L 250 x C 254) }\end{array}$ & $\mathbf{0 , 6 6}$ & $\mathbf{1 , 3 9}$ & $\mathbf{1 , 0 8}$ & $\mathbf{6 , 4 2}$ & $\mathbf{0 , 5 2 0}$ & $\mathbf{0 , 3 3 2}$ \\
$\begin{array}{l}\text { Hybrid 721 } \\
\text { (L 250 x L 358) }\end{array}$ & $\mathbf{- 0 , 1 4}$ & $\mathbf{1 , 7 0}$ & $\mathbf{1 , 4 2}$ & $\mathbf{6 , 7 1}$ & $\mathbf{0 , 5 6 4}$ & $\mathbf{0 , 3 6 2}$ \\
Hybrid 722 & & & & & & \\
(K 730 x C 254) & $\mathbf{0 , 8 3}$ & $\mathbf{2 , 0 7}$ & $\mathbf{1 , 7 3}$ & $\mathbf{5 , 5 8}$ & $\mathbf{0 , 5 0 8}$ & $\mathbf{0 , 2 9 2}$ \\
Hybrid 723 & & & & & & \\
(K 730 x L 358) & $\mathbf{0 , 2 7}$ & $\mathbf{1 , 2 5}$ & $\mathbf{0 , 9 9}$ & $\mathbf{4 , 9 5}$ & $\mathbf{0 , 6 1 0}$ & $\mathbf{0 , 4 2 2}$ \\
Hybrid 725 & & & & & & \\
(K 326 x C 254) & $\mathbf{0 , 9 2}$ & $\mathbf{1 , 8 8}$ & $\mathbf{1 , 2 9}$ & $\mathbf{7 , 1 3}$ & $\mathbf{0 , 5 5 5}$ & $\mathbf{0 , 3 2 0}$ \\
$\begin{array}{l}\text { Hybrid 727 } \\
\text { (K 326 x L 358) }\end{array}$ & $\mathbf{0 , 1 2}$ & $\mathbf{1 , 5 4}$ & $\mathbf{1 , 2 4}$ & $\mathbf{6 , 7 8}$ & $\mathbf{0 , 5 7 6}$ & $\mathbf{0 , 3 4 4}$ \\
\hline
\end{tabular}

Regarding the number of leaves are established lower values of the coefficient of heritability as compared to the height of the plant (Table 2). However, in all investigated crosses exceeds $50 \%$, which is an indication that the effect of genotype is of a greater proportion on the appearance of the number of leaves. Therefore consider that according to number of leaves selection by this feature will be effective still in the early hybrid generations $\left(F_{3}-F_{4}\right)$.

\section{Conclusion}

In our studies hybrid combinations of Virginia tobacco inheritance of plant height and number of leaves uc overdominantly or additive, as in the direction of the parent with the larger values of the expression of the features, and the one with the smaller values.

The number of genes which differ in output parent forms a height of the plant is much bigger than that of number of leaves, where it is very small. On the 
phenotypic expression of plant height, heavily influenced by negative epistative interactions.

Established values of heritability coefficients showed that selection of genotypes with higher stem can begin in the early hybrid generations, but because of negative epistative interactions will be more effective if performed in $\mathrm{F}_{5}-\mathrm{F}_{6}$.

Relatively high values of the coefficient of heritability in terms of number of leaves, are an indication that the selection for the trait will be effective in the early hybrid generations $\left(\mathrm{F}_{3}-\mathrm{F}_{4}\right)$.

\section{References}

Amarnath, S., 1987, Genetic variability in chewing tobacco, Madras Agriculture Journal, 74(10-11); 499-500

Chang, E.Y., C.C. Shyu., 1976, Study of the general and specific combining ability in flue - cured, burley and Turkish tobacco. - Taiwa, Tob. Wine Monop. Bur. To. Res. Inst. Bull., 45, 1-9; Tobacco Abstracts, 21, 4, 1977, Abstract 1035.

Dimanov D., 2003, Herediatability, correlative and regression coefficients of some quantitative characters in somaclonal Oriental tobacco progenies. Genetics and Breeding, Volume 32; Number 3-4 pp.11- 15.

Espino E., M. Gill, 1980, Analysis of the quantitative variation in bright tobacco (N. tabacum) varieties. Cuba tobacco, 2-2, 31-43

Ganusheva N., D. Dimova, N, Toshev, 2001, Genetichen analiz na visochinata i nyakoi priznaci obuslawiasti produktivnosta pri dvuredniq echemik, AU, Nauchni trudove, tom XLVI, кn. 3; 113-117

Ibrahim H. A., N. Avratovscukova, 1982, Phenotypic and genetic variability in guantitative characters of flue-cured tobacco. Bui.Spec. CORESTA, Symposium Winston- Salem, Ab., AP, 1-76

Kaneva, S., 1980, Unasledqiavane na niakoi kolichestveni priznci pri orientalskia tyutyun, Bulgarski tyutyun 4, 14-21

Kirkova S., 2005, Investigation on local and imported Virginia type tobaccs and their mutual replace in cigarette blends. Union of Scientists in Bulgaria - Plovdiv, Scientifics Researches of the Union of Scientists - Plovdiv, Series C. Technics and Technologies, Volume IV, 165-168

Krasteva D., 1983, Nasledyavane ustoychivosta na pepelnica (Erysiphe cichoracearum DC) pri megduvidivi hibridi na sort Pobeda $3 \mathrm{~s}$ ustojchivost ot $\mathrm{N}$. Debneyi, Thesis

Korubin-Aaleksosska A., 2000, Mode of inheritance of some more important morphological characteristics in tobacco varietiesand their diallel croses, Tutun, 50, $1-3,3-12$

Mather, K., and J. L. Jinks, 1985, Biometrical Genetics. Chapman and Hall Ltd., London London New York

Metha L. A., G.J. Patel and B.G. Jaisani, 1985, Genetic analysis of some agro-morphological traits of N. Tabacum, Tobacco Research. 11 (2), 148-154 
Murzova P. Ganusheva N. Velkov N., 2005, Characteristic of perspective rice line, Agricultural University - Plovdiv, Scientific Works, vol.I.book 5, 113-118

Na umovski, K. 1988, Heritability, a genetic index for prediction of breeding results, CORESTA, No 2., p. 49. Abst. 2943

Noveva S., T. Lidanski, R. Vassileva, 1984, Interrelation of genes controlling quantitative characters in intercultivar tobacco hybrids. III. Inheritance of leaf width. Genet.Sel.17-5, pp369-376. Can. J. Genet. Cytol., 23-4, .585-59

Nizam Uddin, M. M.A. Newaz, 1983, Genetic component of variation and hetitabilities in tobacco, Bengladesh J. Agri. Res. 8 (2): 135 -142

Omarov D. S., 1975, On the method of the calculation and evaluation of heterosis in plants, Agricultural biology, Volume X, № 1, 123-127

Peksuslu A., Sabanci C. O., Kücüközden R., S. Sekin, 2002, Genotype $\mathrm{x}$ environment interactions and heritabilities of some important agronomic traits in tobacco, The second Balkan scientific conference quality and efficiency of the tobacco production, treatment and processing, Plovdiv; 80-85

Radoukova, Tz., 2008, Occurrence of basic phenological phases for several species of wheatgrasses at the high-mountain clean of trees area of the "Central Balkans" National Park, Jubilee Conference on Ecology, 1 November 2008, Plovdiv, 47-55.

Risteski I., K. K. Kososka, B. Gveroska, 2012, Results of the investatigation on some bio-morphological characteristks of domestic and introduced varieties of Burley tobacco, Tobacco, vol. 62, № 1-6, 13-21

Sastry A. B., P. V. Prasada Rao, 1980, Genetic analysisi of certain quantitative characters in intervariatal crosses in N. Tabacum. Tobacco Research 6, $32-38$

Shyu C. C., D. C. Lai, E. Y. Chang, 1975, Esimates of hetitability for some important characters in various tobacco crosses,CORESTA. 3-4: 83

Sobolev N. A., 1976. Hybridological analysis of polygenic characters, Cytology and Genetica, X, № 5, 424-436

Stankev G., 2001, Nasledyavane na kolichestveni priznci pri orientalski tyutyun, Bulgarski tyutyun 5, 21-24

Tchinchev B., 1979, Ustanoviavane kombinativna sposobnost na sortove tyutyun Vigrivia po niakoi kolichstveni priznci, Thesis

Torrecila G., A.Barroso, 1980, Metodologia para los caracteres cualitativos de la planta de Tobaco. Ciencia Tecnica Agricultura Tobaco, 3(1):21-61 La Habana

Vasilev D., 2010, Prouchvane na roditelski formi orientalski tyutyun ot proizhod Severna Bulgaria, Thesis 


\title{
NASLEĐIVANJE VISINE BILJAKA I BROJA LISTOVA KOMBINACIJOM HIBRIDA VIRGINIA DUVANA
}

\author{
Yovko Dyulgerski \\ Institut za duvan i duvansku proizvodnju (TTPI), Markovo, Bugarska \\ (e-mail:yovko_dulg@abv.bg) \\ Rezime
}

\begin{abstract}
Ispitivani su nasleđivanje, heterozis i transgresija, broj gena i karakteristike interakcije gena, koeficijent heritabilnosti, kada su u pitanju visina biljke i broj listova kod Virginia duvana. Za ispitivanje su korišćene generacije P1, P2, F1, F2 u sedam hibridnih kombinacija. U našem istraživanju broj listova i visina biljke su dominantno nasledjivane u smeru roditelja sa višim ili nižim vrednostima. Rezultati genetičke analize su pokazali da je broj gena koji utiču na visinu biljke 13-16, a koji utiču nabroj listova 1-2. Sto se tiče visine biljaka utvrđena je negativna epistaza, a za broj listova pozitivna. Uspostavljen je visok koeficijent masledjivanja za visinu biljke i broj listova. Koeficijent heritabilnosti i efikasnosti u odabiru po fenotipu ukazuju da će selekcija genotipova sa većim vrednostima visine biljaka biti efikasnija kod F5-F6, a genotipa sa većim brojem listova kod još ranijih generacija.
\end{abstract}

Ključne reči: Virginia duvan, visina biljke, broj listova, nasleđivanje, hereditabilnost. 